\title{
Obstetric brachial plexus injury in subsequent deliveries
}

MM Al-Qattan FRCSC, AAF El-Sayed FRCSC, TM Al-Kharfy FRCPC FAAP, NAM Al-Jurayyan FRCPC FAAP

Section of Plastic Surgery, Department of Obstetrics and Department of Pediatrics, King Saud University, Riyadh, Saudi Arabia

MM Al-Qattan, AAF El-Sayed, TM Al-Kharfy, NAM Al-Jurayyan. Can J Plast Surg 1996;4(4):203-204. Two cases of obstetrical brachial plexus injury in subsequent deliveries in the same family are described. Medicolegal aspects, review of the literature and recommendations regarding its prevention are given.

Key Words: Birth injury, Birth palsy, Brachial plexus, Obstetric palsy

\section{Lésion obstétricals du plexus brachial lors des accouchements subséquents}

RÉSUMÉ : Deux cas de lésions obstéricales du plexus brachial lors d'accouchements subséquents dans une même famille sont décrits ici. Les aspects médico-légaux, une revue de la littérature et des recommandations au sujet de sa prévention sont également présentés.

Obstetric brachial plexus injury has gained recent attention in the plastic surgery literature because of advances in microsurgery and nerve reconstruction (1-8). Brachial plexus birth palsy is a relatively rare injury and occurs in about one in every 1000 live births. In the modern literature, it is rare to find more than one affected child in the same family. In this paper, we report on obstetric palsy in two subsequent deliveries from the same woman. Medicolegal aspects, a review of the literature and recommendations for prevention of this injury are discussed.

\section{CASE PRESENTATIONS}

\section{Case 1}

A four-year-old girl presented to the brachial plexus clinic in Riyadh, Saudi Arabia with residual left total birth palsy. She was born vaginally at another institution after a full term uncomplicated pregnancy. The presentation was vertex, and delivery was difficult and complicated by shoulder dystocia. At birth, left total birth palsy and an ipsilateral clavicular fracture were evident. Birth weight was $4.4 \mathrm{~kg}$. Good recovery of the motor power occurred, but the functional use of the limb was impaired because of an internal rotation contracture of the shoulder. Rotation osteotomy of the humerus was performed with no complications.

Case 2

A two-year-old boy (brother of case 1) presented at the brachial plexus clinic in Riyadh with residual left Erb's palsy. He was born vaginally at another institution (same 
institution where the sister was born but not delivered by the same obstetrician) after a full term uncomplicated pregnancy. The presentation was vertex, and delivery was difficult and complicated by shoulder dystocia. At birth, an isolated left Erb's palsy was evident. Birth weight was $4.6 \mathrm{~kg}$. Good recovery of the motor power occurred but the functional use of the limb was impaired because of an internal rotation contracture of the shoulder. A soft tissue release procedure is planned.

\section{MATERNAL HISTORY}

The mother of both cases gave birth to a total of six children. The history of the deliveries and the babies' birth weights are given in Table 1. The two children with birth palsy were the only ones born in hospital. Increasing birth weight was also noted in succeeding children.

\section{DISCUSSION}

The hand surgeon is involved in the assessment of birth palsy cases which are frequently medicolegal problems. The skill of an accoucheur may be questioned when several damaged infants are delivered by the same person (9). The most serious charge in the literature was against a French midwife, reported by Guillemot (10) to have delivered more than 30 affected infants. Although both cases presented here were born at the same hospital, but they were not delivered by the same obstetrician. The birth palsy in these cases probably occurred as a result of excessive birth weights (Table 1).

TABLE 1: Children in family

\begin{tabular}{|l|l|l|l|l||}
\hline Child & Sex & Birth weight (kg) & $\begin{array}{l}\text { Presentation/ } \\
\text { delivery }\end{array}$ & Place of delivery \\
\hline 1 st & Male & 3.0 & Vertex/vaginal & Home \\
\hline 2nd & Male & 3.2 & Vertex/vaginal & Home \\
\hline 3rd & Male & 3.3 & Vertex/vaginal & Home \\
\hline 4 th & Female & 3.6 & Vertex/vaginal & Home \\
\hline 5 th* & Female & 4.4 & Vertex/vaginal & Hospital \\
\hline 6 th* & Male & 4.6 & Vertex/vaginal & Hospital \\
\hline
\end{tabular}

*With birth palsy

In multiparas, it is not uncommon to find increasing birth weights in succeeding newborns. Therefore, the potential for birth injury in subsequent pregnancies must be considered when a mother has delivered a large newborn with a brachial plexus injury. In 1973, Gordon et al (11) reported on 34 multiparas who gave birth to infants with birth palsy. Five of the 34 mothers (15\%) had previously delivered infants with a brachial plexus injury. We could not find any study in the literature investigating the actual risk of having a second affected child in a subsequent pregnancy.

After the delivery of a child with birth palsy, should consideration be given to delivery of subsequent infants by caesarean section? It must be recognized, however, that 
caesarean section is not a guarantee against fetal injury. Spinal cord injury, depressed skull fractures, fractures of limb bones and birth palsy have been described in newborns delivered by caesarean section $(5,8,12)$. However, Al-Qattan et al $(8)$ reviewed the English literature over the past decade and found that birth palsy in newborns delivered by caesarean section was extremely rare ( $1 \%$ of all birth palsy cases). This very low incidence was noted despite the fact that all countries report consistent increases in caesarean section rates (average 15\%) over the past decade (13).

In conclusion, multiparas who have previously delivered large infants with a brachial plexus injury should be considered as high risk, and subsequent deliveries should be closely supervised by a qualified obstetrician. Furthermore, consideration could be given to delivery of subsequent infants by caesarean section.

\section{REFERENCES}

1. Al-Qattan MM, Clarke HM. Re: A fourth type of brachial plexus lesion: The intermediate (C7) palsy. J Hand Surg 1994;19B:673.

2. Al-Qattan MM, Clarke HM, Curtis CG. The prognostic value of concurrent clavicular fractures in newborns with obstetric brachial plexus palsy. J Hand Surg 1994;19B:72930.

3. Al-Qattan MM, Clarke HM. A burn caused by the operating microscope light during brachial plexus reconstruction. J Hand Surg 1994;19B:550-1.

4. Clarke HM, Al-Qattan MM, Curtis CG, Zuker RM. Obstetrical brachial plexus palsy: Results following neurolysis of conducting neuromas-in-continuity. Plast Surg Forum 1994;17:90-2.

5. Al-Qattan MM, Clarke HM, Curtis CG. Klumpke's birth palsy. Does it really exist? J Hand Surg 1995;20B:19-23.

6. Clarke HM, Al-Qattan MM, Curtis CG, Zuker RM. Obstetrical rachial plexus palsy: Results following neurolysis of conducting neuromas-in-continuity. Plast Reconstr Surg 1996;97:974-82.

7. El-Sayed AAF, Al-Qattan NM, Clarke HM, Curtis CG. The incidence of Klumpke's birth palsy: Comparison between two decades.

Can J Plast Surg 1996;7:111-3.

8. Al-Qattan MM, El-Sayed AAF, Al-Kharfy TM, Al-Jurayyan NAM. Obstetric brachial plexus injury in newborns delivered by cesarean section. J Hand Surg 1996;21B:263-5.

9. Brown KL. Review of obstetrical palsies. Non-operative treatment. In: Terzis JK, ed. Microreconstruction of Nerve Injuries. Philadelphia: WB Saunders, 1987:499-511.

10. Guillemot Y. Une endemie de paralysis radiculaires obstetricales. Ann Gynecol 1897;47:35-42.

11. Gordon M, Rich H, Deutschberger J, Green M. The immediate and long term outcome of obstetric birth trauma: Brachial plexus paralysis. Am J Obstet Gynecol 1973; 117:516.

12. Groughan-Minihane MS, Petitti DB, Gordis L, Golditch I. Morbidity among breech infants according to method of delivery. Obstet Gynecol 1990;75:831-5.

13. Notzon FC, Placek PJ, Taffel SM. Comparisons of national cesarean section rates. N Eng J Med 1987;316:386-9. 